\title{
Correction to: Belumosudil: First Approval
}

\author{
Hannah A. Blair ${ }^{1}$ \\ Published online: 13 November 2021 \\ (c) Springer Nature 2021
}

\section{Correction to: Drugs (2021) 81:1677-1682 https://doi.org/10.1007/s40265-021-01593-z}

The article Belumosudil: First Approval, written by Hannah A. Blair, was originally published electronically in SpringerLink on 31 August 2021 without open access. After publication volume 81 , issue 14, pages 1677-1682, Kadmon Pharmaceuticals, LLC requested that the article be Open Choice to make the article an open access publication. Postpublication open access was funded by Kadmon Pharmaceuticals, LLC. This article is licensed under a Creative Commons Attribution-NonCommercial 4.0 International License, which permits any non-commercial use, sharing, adaptation, distribution and reproduction in any medium or format, as long as you give appropriate credit to the original author(s) and the source, provide a link to the Creative Commons licence, and indicate if changes were made. The images or other third party material in this article are included in the article's Creative Commons licence, unless indicated otherwise in a credit line to the material. If material is not included in the article's Creative Commons licence and your intended use is not permitted by statutory regulation or exceeds the permitted use, you will need to obtain permission directly from the copyright holder. To view a copy of this licence, visit http://creativecommons.org/licen ses/by-nc/4.0/.
The original article has been corrected.

Open Access This article is licensed under a Creative Commons Attribution-NonCommercial 4.0 International License, which permits any non-commercial use, sharing, adaptation, distribution and reproduction in any medium or format, as long as you give appropriate credit to the original author(s) and the source, provide a link to the Creative Commons licence, and indicate if changes were made. The images or other third party material in this article are included in the article's Creative Commons licence, unless indicated otherwise in a credit line to the material. If material is not included in the article's Creative Commons licence and your intended use is not permitted by statutory regulation or exceeds the permitted use, you will need to obtain permission directly from the copyright holder. To view a copy of this licence, visit http://creativecommons.org/licenses/by-nc/4.0/.

The original article can be found online at https://doi.org/10.1007/ s40265-021-01593-z.

Hannah A. Blair

dru@adis.com

1 Springer Nature, Mairangi Bay, Private Bag 65901, Auckland 0754, New Zealand 